\title{
Comparison of the Number of Population and Attacks Intensity of the Pod Borer (Etiella zinckenella) on Some Varieties of Soybean Crown with Two Cultivation Techniques in Dry Land
}

\author{
B. A. Patu, M. Sarjan, Tarmizi, and Tantawizal
}

\section{ABSTRACT}

Dry land is land that is never flooded or inundated most of the time of the year. Soybeans tend to be planted after the rice harvest in the dry season (MK-I). Soybean planting can be done with two cultivation technologies. The need for soybeans continues to increase along with the increase in population. Efforts to increase soybean productivity have obstacles, one of which is pest attack. One of the most common pests that attack soybeans is the pod borer (Etiella zinckenella I); This research was conducted in Stanggor Village, West Praya District, Central Lombok Regency, from September to December 2020. The experiment used a split plot design with two factors and three replications. The research material was the seeds of five soybean varieties, namely Detap-1, Dega-1, Anjasmoro, Biosoy, and Dena-1 which were planted in 2 different lands, the first land was planted using recommended techniques, and the second was planted using traditional techniques; From these statements, it is known that the use of varieties has no effect on the population of pod borer larvae. The intensity of the pod borer attack is influenced by the environment related to the use of cultivation technology on the life of the pod borer pest, and the pod characteristics of each different soybean variety cause different attack preferences on plants. The population of pod borer larvae has a strong relationship with the intensity of the attack, this is presumably because the higher the pest population, the higher the need for food.

Keywords: Etiella zinckenella, Soybean, Cultivation Techniques, Dryland, Population.

Submitted : September 14, 2021

Published : October 17, 2021

ISSN: $2684-1827$

DOI: $10.24018 /$ ejfood.2021.3.5.377

\section{B. A. Patu *}

Colage Student, Post Graduate, University of Mataram, Indonesia.

(e-mail: bakualoypatu@ gmail.com)

M. Sarjan

Lecture of Post Graduate, University of Mataram, Indonesia.

(e-mail: janjan62@gmail.com)

Tarmizi

Lecture of Post Graduate, University of Mataram, Indonesia.

Tantawizal

Colage Student, Post Graduate, University of Mataram, Indonesia.

(e-mail: Tantowilombok@ gmail.com)

\section{INTRODUCTION}

Dry land is land that is never flooded or inundated most of the time of the year that is used for plant cultivation, and dry land has great potential for agriculture, such as planting food crops, one of which is soybean [1].

Soybeans tend to be planted after the rice harvest in the dry season (MK-I). Soybean planting can be done with two cultivation technologies, the first is done with recommended technology, namely planting using spacing arrangements accompanied by making planting holes by ditugal, the second is done with farmer technology, namely seeds are spread on the planting area. The use of the two technologies is adjusted to take into account the social, economic, cultural, and agroecosystems of soybean planting locations [2]-[4].

Soybean is one of the secondary crops that are often planted by the community because it is profitable and has a high nutritional content, soybeans also have an important role in the contribution of industrial raw materials such as raw materials for making oil, animal feed, and the food industry. Due to the various benefits that soybeans have, soybeans are a much-needed commodity.
The need for soybeans continues to increase along with the increase in population. The total average national demand for soybeans from 2014 to 2018 reached 2.3 to 2.5 million tons annually, this figure is higher than the total national soybean production which is only 1 million tons annually. To meet people's needs for soybeans, the Government imports soybeans an average of 1.1 million tons every year [5], so efforts are needed to increase domestic soybean productivity to reduce soybean imports.

Efforts to increase soybean productivity have problems, one of which is pest attack. [6], there are 15 important pests on soybean plants, one of the pests that most often attacks soybeans is the pod borer (Etiella zinckenella I). Pod borer attacks on various soybean varieties ranged from $26 \%$ to $55 \%$ [7]. [8], the average area of attack by the pod borer in West Nusa Tenggara during 2015 to 2019 reached $220.95 \mathrm{Ha}$, while in Central Lombok Regency it reached 66.45 Ha. One of the soybean production centers in Central Lombok, located in Stanggor Village, in the last few years (2017-2019) experienced crop failure due to the attack of the pod borer pest. Based on the results of interviews with farmers, pod borer pests attack almost $90 \%$ of soybean plants, causing huge losses. 
The purpose of this study was to compare the population and intensity of the soybean pod borer on several soybean varieties with two different cultivation techniques and to determine the relationship between the pod borer pest population and the intensity of the pod borer attack.

\section{MATERIALS AND METHODS}

This research was conducted in Stanggor Village, West Praya District, Central Lombok Regency, from September to December 2020. The experiment used a split plot design with two factors and three replications.

- The first factor is planting technique:

1. $\mathrm{T} 1=$ Recommended technique: stabbing and spacing $40 \times 15 \mathrm{~cm}$.

2. $\mathrm{T} 2=$ Traditional technique: soybean seeds are sewn onto the land to be planted, without planting holes and not using spacing so that the spacing is irregular.

- The second factor is soybean varieties:

1. Detap-1;

2. Dega-1;

3. Anjasmoro;

4. Biosoy;

5. Dena-1.

The research material was the seeds of five soybean varieties, namely Detap-1, Dega-1, Anjasmoro, Biosoy, and Dena-1 which were planted in 2 different lands, the first land was planted using recommended techniques, and the second was planted using traditional techniques.

All data obtained were analyzed for variance, if the treatment had a significant effect, then it was continued with the honest Least Significance Different test (LSD) with a level of 5\%. Regression and correlation analysis is used to examine how the influence and how strong the influence is between parameters.

\section{A. Intensity of Pest Pods Borer}

To determine the intensity of the pod borer attack, the formula for Attack Intensity [9].

$$
\mathrm{I}=\left\{\frac{\mathrm{a}}{\mathrm{b}}\right\} \times 100 \%
$$

$\mathrm{I}=$ Attcak Persentation $(\%)$;

$\mathrm{a}=$ Number of affected pods;

$\mathrm{b}=$ Total Number of Pods

\section{RESULT}

\section{A. Population of Larvae of Pod Borer Pest (Etiella zinckenella)}

The larvae of the pod borer are caterpillars with a body length of 13-15 mm, greenish-yellow in color with red lines [10]. In this study, the population of pod borer larvae (tails/plants) at 10 WAP was the most, namely 15.33 in the cultivation technology treatment using the Biosoy variety, and the population of pod borer larvae (tails/plants) was at least 8.33. on the treatment of recommended cultivation technology with the Anjasmoro variety. Furthermore, at 11 WAP the population of pod borer larvae (tails/plants) was the most, which was 20.72 in the recommended cultivation technology treatment with the Dena variety, and the population of pod borer larvae (tails/plants) was at least 11.44 in the technological treatment. farmer's way of cultivation with the Anjasmoro variety. Furthermore, at 12 WAP, the population of pod borer larvae (tails/plants) was the most, namely 19.44 in the farmer-style cultivation technology treatment with the Dena variety, and the population of pod borer larvae (tails/plants) was at least 9.33 in the technological treatment. cultivation recommendations with the Anjasmoro variety. The influence of cultivation technology and varieties on the population of pod borer larvae can be seen in Table I.

TABLE I: NUMBER OF POPULATION PEDS BORER LARVAE (ETIELLA ZINCKENELLA)

\begin{tabular}{|c|c|c|c|c|}
\hline \multirow{2}{*}{$\begin{array}{c}\text { Observatio } \\
\text { n Age }\end{array}$} & \multirow[b]{2}{*}{ Varieties } & \multicolumn{2}{|c|}{ Cultivation Technique } & \multirow[b]{2}{*}{ Average } \\
\hline & & $\begin{array}{c}\text { Recomendatio } \\
n\end{array}$ & $\begin{array}{c}\text { Tradition } \\
\text { al }\end{array}$ & \\
\hline \multirow[t]{5}{*}{$10 \mathrm{WAP}$} & Detap & 9,00 & 8,67 & 8,83 \\
\hline & Dega & 8,67 & 13,33 & 11,00 \\
\hline & Anjasmoro & 8,33 & 13,00 & 10,67 \\
\hline & Biosoy & 11,00 & 15,33 & 13,17 \\
\hline & Dena & 11,33 & 13,33 & 12,33 \\
\hline Average & & 9,67 & 12,73 & 11,20 \\
\hline \multirow{5}{*}{$\begin{array}{l}11 \text { WAP } \\
\text { BNJ } 0,05 \\
=3,39\end{array}$} & Detap & 12,22 & 12,44 & $12,33 \mathrm{~b}$ \\
\hline & Dega & 13,28 & 13,00 & $13,14 \mathrm{~b}$ \\
\hline & Anjasmoro & 11,54 & 11,44 & $11,49 b$ \\
\hline & Biosoy & 12,33 & 13,33 & $12,83 \mathrm{~b}$ \\
\hline & Dena & 20,72 & 15,67 & 18,19 a \\
\hline Average & & 14,02 & 13,18 & 13,60 \\
\hline \multirow{5}{*}{$\begin{array}{l}12 \text { WAP } \\
\text { BNJ } 0,05 \\
=5,69\end{array}$} & Detap & 12,67 & 11,11 & $11,89 \mathrm{~b}$ \\
\hline & Dega & 9,78 & 12,33 & $11,06 \mathrm{~b}$ \\
\hline & Anjasmoro & 9,33 & 12,22 & $10,78 \mathrm{~b}$ \\
\hline & Biosoy & 12,56 & 16,00 & $14,28 \mathrm{ab}$ \\
\hline & Dena & 18,78 & 19,44 & $19,11 \mathrm{a}$ \\
\hline Average & & 12,62 & 14,22 & 13,42 \\
\hline
\end{tabular}

Note: The numbers in the same column followed by the same letter indicate that they are not significantly different at the 5\% level of the Tukey HSD test.

From the results of ANOVA, it was known that at $10 \mathrm{WAP}$ the treatment of cultivation technology and the varieties tested did not affect the population of Pod Borer Pest larvae (Etiella zinckenella) because the average number of larvae in each variety was not significantly different. At 11 WAP the treatment of varieties independently affected the total population of pod borer larvae; the treatment of Dena variety was significantly different from other varieties. At 12 WAP the treatment of cultivation technology and varieties independently affected the number of larvae of the pod borer pest, the treatment of Dena variety was significantly different from the Detap, Dega, Biosoy varieties, and not significantly different from the Biosoy variety.

At 10 WAP the treatment tested had no effect on the larval population, presumably because at the age of 10 WAP, the environment related to cultivation technology did not affect the larvae, and the characteristics of the pods at the age of 10 WAP had not sufficiently affected the larval population. At the age of $11 \mathrm{WAP}$ and $12 \mathrm{WAP}$, the larval population was influenced by the variety, presumably because the pods had been able to affect the population with their respective pod morphology characteristics such as pod skin thickness, pod shell texture, trichome length, and trichome density, thus causing differences in the population of pod borer pests between one variety. with other varieties. 
In reference [11], from several varieties tested that the results were not significantly different from one variety to another in the number of larvae in soybean plants. [12] the number of larvae in several varieties tested showed no significantly different results. From these statements, it is known that the use of varieties has no effect on the population of pod borer larvae. In this study, varieties affected the age of $11 \mathrm{WAP}$ and $12 \mathrm{WAP}$, the differences between the results of [11], and [12] with this study it is suspected that there is a random influence on the selection of soybean varieties.

\section{B. Intensity of Pod Borer Pests (Etiella zinckenella)}

The intensity of pod borer attack is the number of attacked pods compared to the number of healthy pods, from this comparison it can be seen the strength of pests that can damage plant pods [13]. In this study, the intensity of the pod borer pest was highest at the age of 10 WAP, namely 43.19 in the treatment of farmer-style cultivation technology with the Dega variety, and the lowest at 19.46 in the treatment of recommended cultivation technology with the Anjasmoro variety. At the age of $11 \mathrm{WAP}$, the intensity of the pod borer pest was the highest at 48.6 in the treatment of farmer-style cultivation technology with the Dega variety, and the lowest at 18.73 in the recommended cultivation technology treatment with the Anjasmoro variety. At the age of 12 WAP, the intensity of the pod borer pest was the highest at 42.28 on the recommended cultivation technology treatment with the Dega variety, and the lowest at 15.46 in the recommended cultivation technology treatment with the Anjasmoro variety. The effect of the tested treatments on the intensity of the pod borer attack can be seen in Table II.

TABLE II: INTENSITY OF POD BORER PESTS (ETIELLA ZINCKENELLA) AGE 10 WAP, 11 WAP, AND 12 WAP, RESPECTIVELY

\begin{tabular}{|c|c|c|c|c|}
\hline \multirow{2}{*}{$\begin{array}{c}\text { Observation } \\
\text { Age }\end{array}$} & \multirow{2}{*}{ Varieties } & \multicolumn{2}{|c|}{ Cultivation Technique } & \multirow{2}{*}{ Average } \\
\hline & & Recommendation & Traditional & \\
\hline \multirow{5}{*}{$\begin{array}{c}10 \text { WAP } \\
\text { BNJ } 0,05= \\
13,87\end{array}$} & Detap & $18,75 \mathrm{bc}$ & $21,17 \mathrm{bc}$ & 19,96 \\
\hline & Dega & $21,02 \mathrm{bc}$ & 43,19 a & 32,11 \\
\hline & Anjasmoro & $15,46 \mathrm{bcd}$ & $28,46 b c$ & 21,96 \\
\hline & Biosoy & $21,05 \mathrm{bc}$ & $35,35 \mathrm{ab}$ & 28,2 \\
\hline & Dena & $19,86 \mathrm{bc})$ & $30,02 \mathrm{abc}$ & 24,94 \\
\hline Average & & 19,23 & 31,64 & 25,43 \\
\hline \multirow{5}{*}{$\begin{array}{c}11 \text { WAP } \\
\text { BNJ } 0,05= \\
13,04\end{array}$} & Detap & 19,29 & 29,87 & $24,58 \mathrm{~b}$ \\
\hline & Dega & 32,65 & 48,6 & $40,63 \mathrm{a}$ \\
\hline & Anjasmoro & 18,73 & 26,71 & $22,72 \mathrm{~b}$ \\
\hline & Biosoy & 27,49 & 41,74 & $34,62 \mathrm{ab}$ \\
\hline & Dena & 30,2 & 35,63 & $32,92 \mathrm{ab}$ \\
\hline \multirow[t]{2}{*}{ Average } & & 25,67 & 36,51 & 31,09 \\
\hline & Detap & 19,64 & 25,57 & $22,61 \mathrm{bc}$ \\
\hline \multirow{4}{*}{$\begin{array}{c}12 \text { WAP } \\
\text { BNJ } 0,05= \\
13,87\end{array}$} & Dega & 25,11 & 42,28 & $33,70 \mathrm{ab}$ \\
\hline & Anjasmoro & 18,17 & 23,65 & $20,91 \mathrm{c}$ \\
\hline & Biosoy & 33,55 & 38,15 & $35,85 \mathrm{ab}$ \\
\hline & Dena & 34,12 & 41,14 & $37,63 \mathrm{a}$ \\
\hline Average & & 26,12 & 34,16 & 30,14 \\
\hline
\end{tabular}

Note: The numbers in the same column followed by the same letter indicate that they are not significantly different at the 5\% level of the Tukey HSD test.

From the results of ANOVA, it is known that the intensity of the pod borer pest attack at $10 \mathrm{WAP}$ is influenced by the interaction of the treatment of cultivation technology with the variety Biosoy and is significantly different from other varieties. At 11 WAP the intensity of the pod borer pest was independently affected by the varietal treatment, the application of the Dega variety was not significantly different from the Dena, Biosoy varieties and significantly different from the Detap and Anjasmoro varieties. At 12 WAP the intensity of the pod borer pest was independently affected by the varietal treatment, the treatment of the Dena variety was not significantly different from the Biosoy, Dega varieties and significantly different from the Detap and Anjasmoro varieties.

At 10 WAP the interaction of cultivation technology treatment with varieties can affect the intensity of pod borer pests. It is suspected that at the age of $10 \mathrm{WAP}$ the pods are still relatively young, and the pod development is sensitive to environmental conditions, each variety has differences in adapting to the environment related to cultivation technology. , thus causing an influence on the preference of pests to attack plants. At 11 WAP and 12 WAP, the intensity of the attack was only affected by the variety, this was presumably because of the age of 11 WAP and 12 WAP hatched larvae that had been able to adapt to the environment and what was able to influence the preference of pests to attack was the difference in pod characteristics of each variety.

[14] environmental factors (temperature, humidity, light) affect the life of pests and support an active level of life, especially on food quality. [15] from several spacing treatments that were tested against the intensity of pod borer attacks, the results were significantly different from one treatment to another. [9], the intensity of pod borer attacks on several soybean varieties tested showed significantly different results, this was due to the different characteristics of the pods of each variety. [16] the level of pod borer pests of several soybean varieties tested showed significantly different results, one of the factors that influenced these differences was the physical differences of the pods of each variety.

From these statements, it is known that the intensity of pod borer attack is influenced by the environment related to the use of cultivation technology on the life of the pod borer pest, and the pod characteristics of each different soybean variety cause different attack preferences on plants.

\section{Relationship between Larvae Population and Intensity of Pod Borer Pests}

In this study, it was found that the population of pod borer larvae was related to the average intensity of pod borer attacks at 10,11, and 12 WAP. The intensity of the pod borer can be seen in graph 1 .

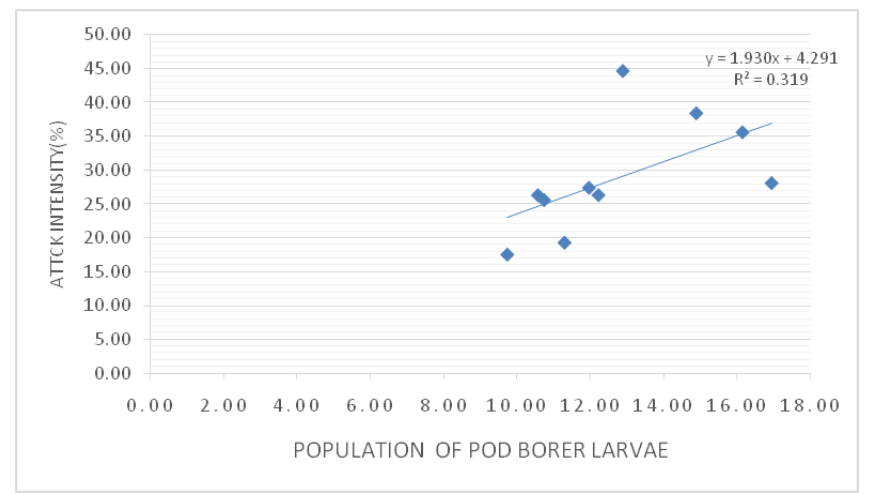

Fig. 1. Relationship between pod borer larvae population and average attack intensity of pod borer 10,11 , and 12 WAP.

In Fig. 1. From the results of the regression analysis and correlation between the Average population of pod borer and the Average intensity of pod borer attacks 10, 11, and 12 WAP, it shows that the addition of the value to the $\mathrm{X}$ factor (Larva Population) will affect the addition of the value to the 
$\mathrm{Y}$ factor (Intensity of Attack). with a value of 1.9306, if $\mathrm{X}=$ 0 then $\mathrm{Y}=4.2917$ and for the value of R2 in the relationship that is $0.3192(31 \%)$ or the relationship between flowering age and the intensity of the pod borer pest attack 10, 11 and 12 WAP has high strength weak.

[17] the high population of pod borer larvae increased the intensity of damage to the pods. [12], based on correlation analysis showed that the higher the larval population, the higher the intensity of the damage. [9] the high attack intensity was caused by the high population of pod borer larvae.

From some of these statements, it is known that the population of pod borer larvae has a strong relationship with the intensity of the attack, this is presumably because the higher the pest population, the higher the need for food, limited soybean pods accompanied by a high pest population causes an imbalance between food sources and population. pests so that the intensity of attack is higher.

\section{CONCLUSION}

The conclusions in this study are:

1. The population of pod borer larvae (tails/plants) at 10 WAPs was at most 15.33 in the cultivation technology treatment using the Biosoy variety, and the population of pod borer larvae (tails/plants) was at least 8.33 in technology treatment. cultivation recommendations with the Anjasmoro variety. Furthermore, in 11 WAP the population of pod borer larvae (tails/plants) was the most, namely 20.72 in the recommended cultivation technology treatment with the Dena variety, and the population of pod borer larvae (tails/plants) was at least 11.44 in the technological treatment. farmer's way of cultivation with the Anjasmoro variety. Furthermore, in 12 WAP the population of pod borer larvae (tails/plants) was at most 19.44 in the treatment of farmerstyle cultivation technology with the Dena variety, and the population of pod borer larvae (tails/plants) was at least 9.33 in the technological treatment. cultivation recommendations with the Anjasmoro variety. The intensity of the pod borer pest was highest at the age of 10 WAP, namely 43.19 in the treatment of farmer-style cultivation technology with the Dega variety, and the lowest at 19.46 in the treatment of recommended cultivation technology with the Anjasmoro variety. At the age of $11 \mathrm{WAP}$, the intensity of the pod borer pest was highest at 48.6 in the treatment of farmer-style cultivation technology with the Dega variety, and the lowest at 18.73 in the recommended cultivation technology treatment with the Anjasmoro variety. At the age of 12 WAP, the intensity of the pod borer pest was the highest at 42.28 in the recommended cultivation technology treatment with the Dega variety, and the lowest at 15.46 in the recommended cultivation technology treatment with the Anjasmoro variety.

2. The results of regression analysis and correlation between the average population of pod borer and the average intensity of pod borer attack 10, 11, and 12 WAP show that the addition of the value to factor X (Larva Population) will affect the addition of the value to factor Y (Intensity of Attack) with a value of 1.9306 . , if $X=0$ then $Y=4.2917$ and for the R2 value, the relationship is $0.3192(31 \%)$, or the relationship between flowering age and the intensity of pod borer attacks 10, 11 and 12 WAP has a weak strength.

\section{REFERENCE}

[1] A. Abdurachman, A. Dariah, A. Mulyani, "Strategi Dan Teknologi Pengelolaan Lahan Kering Mendukung Pengadaan Pangan Nasional," Jurnal Litbang Pertanian, Vol. 2., No. 27, pp. 43-49, 2008.

[2] Sudaryono, "Inovasi Rekayasa Teknologi Pengelolaan Tanaman Terpadu Kedelai,” Buletin Palawija, Vol. 1., No. 13, pp. 16-28, 2007.

[3] M. Kinasih, R. Wirosodarmo, B. R. Widiatmono, "Analisis Ketersediaan Air terhadap Potensi Budidaya Kedelai (Glycine max (L) Merril) di Daerah Irigasi Siman," Jurnal Sumberdaya Alam dan Lingkungan, Vol. 1., No. 1, pp. 57-62, 2015.

[4] A. K. Zakaria, "Dampak Penerapan Teknologi Usahatani Kedelai Di Agrosistem Lahan Kering Terhadap Pendapatan Petani," Agrika, Vol. 4. No. 2, pp. 67-78, 2010.

[5] Ministry of Agriculture. 2019. Food Security Statistics 2018.

[6] Marwoto, S. Hardaningsih, A. Taufiq, "Hama, Penyakit, Dan Masalah Hara Pada Tanaman Kedelai: Identifikasi Dan Pengendaliannya," IAARD Press. Jakarta, 2013

[7] M. S. Bayu, Tantawizal, Y. Prayogo, "Tingkat Serangan Penggerek Polong Pada Genotipe Kedelai Toleran Ulat Grayak. Di dalam: Prosiding Seminar Hasil Penelitian Tanaman Aneka Kacang dan Umbi," Malang, 2013. pp. 310-315.

[8] West Nusa Tenggara Agricultural Crop Protection Center. 2019. Extensive Cumulative Data Adds Major OPT Attacks of Soybeans for the Last 5 Years West Nusa Tenggara.

[9] W. A. S. Gatut, M. A. Muchlish, "Penciri Ketahanan Morfologi Genotipe Kedelai terhadap Hama Penggerek Polong," Jurnal Penelitian Pertanian Tanaman Pangan, Vol. 27., No. 2, pp. 95-100, 2008.

[10] Tantawizal, Christanti, W. Tengkano, "Spesies, Perbandingan Kelamin, Dan Ciri Morfologi Penggerek Polong Kedelai Etiella Sp., Di Kebun Percobaan Ngale," Di dalam: Prosiding Seminar Hasil Penelitian Tanaman Aneka Kacang dan Umbi, 2011, pp. 302-309.

[11] F. Pasaribu, S. Dan Desita, "Seleksi Genotipe Kedelai (Glycine max L. Merril) untuk Ketahanan terhadap Penggerek Polong Kedelai, Etiella zinckenella Treitschke (Lepidoptera: Pyralidae)," J. Agrotek. Trop, Vol. 6., No. 2, pp. 76-82, 2017.

[12] B. P. Arlyna, W. B. Sri, B. B. Utomo, A. Arif, S. Eko, "Populasi Dan Intensitas Serangan Hama Pada Beberapa Varietas Kedelai Di Lahan Kering Gunung Kidul,” Di dalam: Prosiding Seminar Hasil Penelitian Tanaman Aneka Kacang dan Umbi, 2012, pp. 265-271.

[13] N. P. M. Rusyana, I. G. N. Bagus, A. A. A. S. Sunarni, "Populasi dan Serangan Hama Polong Kedelai Etiella zinckenella (Treitschke) (Lepidoptera: Pyralidae) yang Diperlakukan dengan Insektisida Berbahan Aktif Klorpirifos 500 g/l dan Sipermetrin 50 g/l," E-Jurnal Agroekoteknologi Tropika, Vol. 7, No. 2, pp. 192-199, 2018.

[14] Yasin, Muhammad. Kemampuan Akses Makan Serangga Hama Kumbang Bubuk Dan Faktor Fisikokimia Yang Mempengaruhinya. Di dalam: Prosiding Seminar Nasional Serealia, 2009. pp. 400-409.

[15] J. S. Sartono, Siswadi, I. Elly, F. Lulus, W. A. Arif, "Kajian Macam Jarak Tanam Pada Tiga Varietas Kedelai Terhadap Itensitas Serangan Hama dan Patogen," Research Fair Unisri, Vol. 4, No. 1, pp. 95-106, 2019.

[16] A. Rahman, A. dan Fattah, "Ketahanan Beberapa Varietas Unggul Kedelai Terhadap Ulat Grayak Dan Penggerek Polong. Di dalam: Prosiding Seminar Hasil Penelitian Tanaman Aneka Kacang dan Umbi," 2015, pp. 110-116.

[17] Suharsono, "Antixenosis Morfologis Salah Satu Faktor Ketahanan Kedelai Terhadap Hama Pemakan Polong," Buletin Palawija, Vol. 1, No. 11, pp. 29-34, 2006. 